\title{
Hubungan Keterampilan Sosial Terhadap Prestasi Belajar Siswa Kelas IV Sekolah Dasar
}

\author{
Angga Putra ${ }^{1}$, Putri Surya Damayanti ${ }^{2}$, Nurahmawati ${ }^{3}$ \\ 1,2,3 Program studi Pendidikan Guru Skolah Dasar, STKIP Yapis Dompu \\ E-mail corresponding: stkipangga@gmail.com
}

Article History: Received: 2021-07-22 || Revised: 2021-07-28 || Published: 2021-08-26

Sejarah Artikel : Diterima: 2021-07-22 || Direvisi: 2021-07-28 || Dipublikasi: 2021-08-26

\begin{abstract}
The problem in this study is the number of students who in their learning activities do not cooperate in doing group assignments, do not want to help their friends who have difficulty understanding the learning material, some even choose favoritism, namely only helping their best friends even within the scope of their play, Therefore, this study aims to see or find out related to the social skills possessed by students in their learning, including their learning achievement in school, learning so that student learning achievement is also maximized, because students' social skills will be more developed if they are always given support in the form of enthusiasm and moral messages from the teacher, this is based on research that has been done. Based on scientific studies with the support of research results and studies of supporting theories, it can be concluded that children's emotions are closely related to student achievement, therefore, the results of this study can be a source of reference for teachers that children's emotions are closely related to student achievement in school.
\end{abstract}

Keywords: Social, Skills, Learning Outcomes.

\begin{abstract}
Abstrak
Permasalahan dalam penelitian ini adalah banyaknya siswa yang dalam kegiatan pembelajarannya kurang bekerja sama dalam mengerjakan tugas kelompok, tidak mau membantu temannya yang kesulitan dalam memahami materi pembelajaran, bahkan ada yang pilih kasih yaitu hanya membantu teman baiknya saja bahkan dalam lingkup bermainnya, oleh karena itu, Penelitian ini bertujuan untuk melihat atau mengetahui terkait dengan keterampilan sosial yang dimiliki siswa dalam pembelajarannya, termasuk prestasi belajarnya di sekolah.Adapun hasil penelitian yang dilakukan serte beberapa teori yang mendukung menyatakan bahwa ternyata guru harus mendukung dan memaksimalkan keterampilan emosional anak dalam kegiatan pembelajarannya sehingga prestasi belajar siswa juga maksimal, karena keterampilan social siswa akan lebih berkembang jika selalu diberikan dukungan dalam bentuk semangat maupun pesan moral dari guru, hal itu berdasarkan penelitian yang telah dilakukan, berdasarkan pengkajian secara ilmiah dengan dukungan hasil penelitian dan kajian teori pendukung, maka dapat disimpulkan bahwa emosional anak sangat berhubungan dengan prestasi belajar siswa, oleh karena itu hasil penelitian ini dapat menjadi sumber referensi guru bahwa emosional anak berhubungan erat dengan prestasi belajar siswa di sekolah.
\end{abstract}

Kata kunci: Sosial, Skill, Hasil Belajar.

\section{PENDAHULUAN}

Pendidikan adalah wadah yang berupaya untuk membantu membebaskan masyarakat dari kebodohan dan keterbelakangan, pendidikan memegang peranan yang sangat penting dalam kemajuan, baik dari segi fisik maupun dari segi psikis, dengan adanya pendidikan, manusia dapat menyadari bahwa pentingnya memanusiakan manusia dari titik terlemah dalam hidupnya, setiap individu di dalam dunia pendidikan memiliki peranan penting yang saling membutuhkan satu sama lain, individu tersebut selalu menyesuaikan diri dengan lingkungannya, sehingga kepribadian individu, kecakapan-kecakapannya, ciri-ciri kegiatannya baru menjadi kepribadian individu yang sebenar-benarnya apabila keseluruhan sistem psychophysik tersebut berhubungan langsung dengan lingkungannya (Ahmadi, A, 2017: 247), oleh karena itu keterampilan sosial siswa merupakan bagian penting dalam dunia pendidikan siswa.

Keterampilan sosial adalah kemampuan individu untuk berkomunikasi secara efektif dengan orang lain baik verbal maupun nonverbal sesuai dengan situasi dan kondisi yang ada pada saat itu, di mana keterampilan ini merupakan perilaku yang di pelajari, anak dengan keterampilan sosial akan mampu mengungkapkan 
perasaan baik positif maupun negatif dalam hubungan interpersonal, tanpa harus melukai orang lain. Hargie, Saunders, \& Dickson (dalam Yulia, 2010: 19), sedangkan menurut salah satu pakar psikologys, Golemen (dalam Fahmi. 2014: 15), keterampilan sosial adalah kemampuan seseorang untuk menangani emosi dengan baik ketika berhubungan dengan orang lain secara cermat, membaca situasi jaringan sosial, berinteraksi dengan lancar, menggunakan keterampilan-keterampilan ini untuk mempengaruhi, memimpin, menyelesaikan perselisihan serta untuk bekerja sama di dalam tim, Menurut Poerwanto (dalam Nugroho: 2009. 15), prestasi adalah hasil yang telah di capai dari apa yang telah dilakukan, dikerjakan, di usahakan dan sebagainya. Sedangkan menurut Oemar Hamalik (dalam Yusuf \& Legowo: 2007..10), bahwa prestasi adalah bentuk pertumbuhan atau perubahan dari dalam diri seseorang yang dinyatakan dengan cara-cara tingkah laku yang baru, berkat pengalaman dan latihan yang ditunjukan dengan nilai rapor, maka dapat dijelaskan bahwa prestasi belajar merupakan keberhasilan seseorang dalam mempelajari materi pelajaran yang dinyatakan dalam bentuk nilai atau raport disetiap bidang studi setelah mengalami proses pembelajaran. Prestasi belajar siswa dapat di ketahui setelah di adakaan evaluasi, hasil dari evaluasi dapat memperlihatkan tentang tinggi atau rendahnya prestasi belajar siswa.

Dengan demikian, maka prestasi belajar siswa memiliki hubungan erat dengan lingkungan sosial siswa yang berkaitan dengan keterampilan sosial siswa, anak berprestasi baik memiliki nilai raport tinggi dengan skor nilai di atas 90, termasuk kategori baik dalam hal bersosial, anak dengan prestasi buruk memiliki nilai raport rendah dengan skor nilai di bawah 70, termasuk kategori kurang baik dalam bersosial dengan lingkungan dan pembelajaran karena cenderung kurang aktif dalam ruang lingkup sosial, berdasarkan hasil observasi awal yang dilakukan tanggal 15 Bulan April 2020 dengan guru kelas/wali kelas IV di SDN 1 PAJO, di peroleh informasi bahwa ada beberapa permasalahan yang kerap ditemukan dilapangan yaitu: Ketika tugas kelompok diberikan, cenderung beberapa siswa memilih mengerjakan soal sendiri-sendiri, anak perempuan memilih mengerjakan soal dengan teman perempuannya, begitu pula sebaliknya dengan yang laki-laki, Beberapa siswa pula tidak mau membantu temannya yang kesulitan memahami pembelajaran, Ketika pembelajaran berlangsung, beberapa siswa terkadang suka berbicara sendiri di dalam kelas, pada jam istirahat, siswa membuat kelompok bermain sendiri-sendiri yang di dominasi oleh siswa yang dominan dikelasnya, sehingga yang lemah cenderung tertindas dan siswa yang dominan sering mengejek siswa yang lemah dengan sebutan yang tidak disukai bahkan sampai terjadi kontak fisik.

Berdasarkan uraian diatas, maka peneliti tertarik untuk melakukan penelitian dengan judul "Hubungan keterampilan sosial siswa terhadap prestasi belajar siswa kelas IV SDN 1 PAJO Tahun Pembelajaran 2020/2021, upaya untuk menguatkan pemikiran peneliti dalam menyikapi permasalahan diatas, indikator yang diambil oleh peneliti dalam menyusun rancangan penelitian ini diambil dari dimensi keterampilan social, secara teori ada 5 (lima) dimensi paling umum yang terdapat didalam keterampilan sosial, yaitu : 1). Hubungan dengan teman sebaya (Peer relation), 2). Manajemen diri (Self-management), 3). Kemampuan akademis (Academic). 4). Kepatuhan (Compliance), 5). Perilaku assertive (Assertion).

\section{METODE PENELITIAN}

Penelitian ini menggunakan pendekatan kuantitatif, dengan jenis korelasional, penelitian ini difokuskan pada pencarian hubungan antara dua variabel, variabel bebas adalah keterampilan sosial dan variabel terikat adalah prestasi belajar, populasi dalam penelitian ini dibedakan menjadi dua, yaitu populasi secara umum dan populasi target, populasi target adalah populasi yang menjadi sasaran kesimpulan penelitian, yang menjadi populasi umum dalam penelitian ini adalah SDN 1 PAJO, adapun populasi target dalam penelitian ini adalah siswa kelas IV yang ada di SDN 1 PAJO, sedangkan teknik pengambilan sampel yang digunakan dalam penelitian ini yaitu purposive sampling dari Nonprabability sampling, Purposive sampling adalah tekhnik penentuan sampel dengan pertimbangan tertentu yang bertujuan supaya data yang diperoleh lebih representative, (Sugiyono, 2017: 85), adapun jumlah sampel yang digunakan dalam penelitian ini ada pada Kelas IV SDN 1 PAJO yaitu sebanyak 26 orang atau total sampling.

Teknik pengumpulan data yang digunakan dalam penelitian ini diantaranya: 1) Angket atau kuesioner merupakan teknik pengumpulan data yang dilakukan dengan cara memberi seperangkat pertanyaan atau pernyataan tertulis kepada responden untuk dijawabnya (Sugiyono 2017: 142), Angket dalam penelitian ini adalah kumpulan pernyataan yang di susun oleh peneliti dan akan di jawab oleh responden, Angket yang di gunakan merupakan angket terbuka, dan skala dalam penelitian ini adalah skala likert yaitu skala untuk mengukur sikap, pendapat dan persepsi seseorang atau sekelompok orang tentang fenomena sosial. Untuk keperluan analisis data maka jawaban dari pernyataan atau pertanyaan dapat diberi skor, misalnya setuju 5, sering 4, kadang-kadang 3, tidak setuju 2, dan sangat tidak setuju 1, 2) Dokumentasi, dokumentasi dalam penelitian ini bertujuan untuk memperoleh data prestasi belajar siswa meliputi nilai hasil akhir siswa (raport), dan ujian akhir semester Tahun Pembelajaran2020/2021. 
Adapun teknik analisis data yang digunakan dalam penelitian ini dengan cara mengelompokkan data berdasarkan variabel dan jenis responden, mentabulasi data berdasarkan variabel dari seluruh responden, menyajikan data tiap variabel yang diteliti, melakukan perhitungan untuk menguji hipotesis yang telah diajukan, Analisis data yang digunakan untuk melihat hubungan antara keterampilan sosial dengan prestasi belajar adalah dengan menggunakan korelasi dari spearman, Rumus korelasi Spearman, penjelasannya yaitu sebagai berikut:

$$
\begin{aligned}
& r s=1-\frac{6 \sum_{i=1}^{n} d_{i}^{2}}{N\left(n^{2}-N\right.} \\
& \text { Keterangan: } \\
& r s=\text { koefisien korelasi spearman } \\
& d i=\text { perbedaan skor antar } 2 \text { variabel } \\
& N=\text { jumlah data } \\
& \text { (winarsunu, 2017: 153-1v57) }
\end{aligned}
$$

Penghitungan akan dilakukan dengan bantuan komputer program SPSS, untuk mengetahui keeratan hubungan antara kedua variabel, Peneliti menggunakan pedoman interpretasi koofisien korelasi statistic yang sudah tersedia. Berikut adalah pedoman untuk memberikan interpretasi koofisien korelasi.

\section{HASIL DAN PEMBAHASAN}

Pada pembahasan ini akan di jabarkan terkait dengan hasil analisis data. data-data yang akan di jabarkan pada pembahasan ini mempunyai arti penting bagi seluruh rangkaian penelitian, datadata yang masih bersifat terpisah atau mentah diolah dan dijabarkan dalam upaya untuk menjawab masalah penelitian dan / atau tujuan penelitian, pada penelitian ini menggunakan motode penelitian kuantitatif korelasional. Metode penelitian pada dasarnya merupakan cara ilmiah untuk mendapatkan data dengan tujuan dan kegunaan tertentu. Berdasarkan hal tersebut terdapat empat kata kunci yang perlu di perhatikan yaitu, cara ilmiah, data, tujuan dan kegunaan, Cara ilmiah berarti kegiatan ilmiah yang di dasarkan pada cici-ciri keilmuan, yaitu rasional, empiris, dan sistematis, (Sugiono, 2017:2), seperti yang di jelaskan sebelumnya, pembahasan ini bertujuan untuk menjawab masalah penelitian dan menjelaskan bagaimana tujuan penelitian itu di capai.

Pada penelitian ini terdapat dua variabel yang di gunakan, dimana variabel keterampilan sosial sebagai variable terikat, sedangkan variabel prestasi belajar di gunakan sebagai variabel bebas.Data variabel keterampilan sosial di peroleh dari kuesioner skala Likert yang terdiri dari 26 item pernyataan dengan empat alternatif jawaban, dimana 4 untuk skor tertinggi dan 1 untuk skor terendah, pengisian skala di lakukan di kelas dengan bimbingan peneliti, peneliti juga menggunakan teknik wawancara untuk menguatkan data variabel keterampilan social, wawancara di lakukan dengan menanyakan butir skala yang belum di isi lengkap oleh responden, variabel prestasi belajar merupakan variabel bebas dalam penelitian ini, dimana variabel ini datanya diambil langsung dari nilai ujian semester siswa tanpa di ubah lagi, artinya di dalam penelitian ini, nilai-nilai yang telah di berikan oleh guru tidak lagi diganggu gugat oleh peneliti.

Seperti yang di katakan sugiono (2017:2) penelitian itu harus memenuhi ciri-ciri keilmuan, rasional, empiris, dan sistematis, rasional berarti kegiatan penelitian itu di lakukan dengan caracara yang masuk akal, sehingga terjangkau oleh penalaran manusia, empiris berarti cara-cara yang di lakukan itu dapat di amati oleh indera manusia, sehingga orang lain dapat mengetahui cara-cara yang di gunakan, sistematis artinya, proses yang di gunakan dalam penelitian itu menggunakan langkah-langkah tertentu yang bersifat logis, dalam upaya untuk menenuhi syarat di atas, instrumen yang di gunakan dalam penelitian ini telah melewati tahap validitas oleh dosen, setelah instrumen di nyatakan layak oleh dosen, maka peneliti turun kelapangan untuk memenuhi syarat dari skripsi peneliti yaitu menjawab masalah penelitian dan menunjukkan bagaimana tujuan itu di capai, dan juga untuk memenuhi syarat dari ciri-ciri keilmuan yaitu rasional, empiris, dan sistematis.

Setelah melewati tahap penelitian di lapangan, maka tahapan selanjutnya adalah tahapan analisis data yang harus di lewati, data-data yang akan di analisis adalah data keterampilan sosial yang di 
ambil dari kuisioner dan data prestasi belajar di ambil dari nilai rapor. Karena datanya bersifat kuantitatif, maka tekhnik analisis data yang akan di gunakan sudah jelas yaitu menggunakan statistik yang sudah tersedia, Berikut adalah susunan uji statistic yang digunakan dan telah di analisis oleh peneliti untuk menjawab rumusan masalah dari penelitian.

Sebelum melakukan uji korelasi, peneliti ingin menunjukkan terlebih dahulu penelitian yang relavan dengan penelitian ini, Judul penelitian yaitu: Hubungan interaksi Sosial Dengan Prestasi Belajar Siswa Kelas VII SMP N 24 Kota Jambi oleh Singki Oktaviani Nim : ERA 1 D 009100, Populasi dan sampel penelitian yang diambil didalam penelitian ini sebesar 37 siswa, Angket yang digunakan adalah metode skala linker (4 pilihan) yaitu setuju, kurang setuju, tidak setuju dan sangat tidak setuju. Yang dimana setuju di beriskor (4), kurang setuju di beriskor (3), tidak setuju di beriskor (2) dan sangat tidak setuju di beri skor (1), Pengolahan data pada penelitian ini adalah menggunakan uji korelasi produck moment, yang dimana sebelum melakukan rumus tersebut harus di uji terlebih dahulu Normalitas datanya melalui uji normalitas, pada penelitian ini hasil dari SPSS 21 menyatakan symp. Sig > 0,05 maka H0 normal, sedangkan pada $r$ hitung ditemukan hasil 0,872 yang signifikan pada p .002, Dengan demikian Ho di tolak dan Ha diterima Ha=rxy>0 sehingga hipotesis yang menyatakan terdapat terdapat korelasi tinggi :hubungan besar antara keterampilan social dengan prestasi belajar.

Dari hasil penelitian di atas menguatkan keinginan peneliti untuk menggunakan metode yang sama untuk mengetahui seberapa besar hubungan keterampilan sosial dengan prestasi belajar, berikut adalah hasil analisis peneliti untuk mengetahui keeratan hubungan kedua variable, Pengujian korelasi adalah pengujian yang bertujuan untuk menguji hubungan antara dua variabel. Pengujian ini apabila jumlah sampel di atas 30 dan datanya berdistribusi normal, sebaiknya menggunakan rumus dari Pearson, karena telah memenuhi persyaratan statistik parametric, jika jumlah sampel kecil dan berdistribusi tidak normal maka sebaiknya menggunakan korelasi dengan rumus dari Spearman atau statistik non parametric (Susetyo, 2017: 281), Jumlah sampel pada penelitian ini sebesar 26 orang. Seperti yang telah di jelaskan oleh susetio di atas, Jika jumlah sampel kecil dan berdistribusi tidak normal maka sebaiknya menggunakan korelasi dengan rumus dari spearman atau statistic non parametric, dengan adanya pandangan di atas, perhitungan dalam penelitian ini menggunakan rumus dari Spearman atau statistik non parametric, Hipotesis penelitian yang akan di uji adalah terdapat hubungan keterampilan sosial dengan prestasi belajar.

\begin{tabular}{|c|c|c|c|c|}
\hline \multicolumn{5}{|c|}{ Correlations } \\
\hline & & & $\begin{array}{l}\text { Keterampilan } \\
\text { Sosial }\end{array}$ & Prestasi Belajar \\
\hline \multirow[t]{6}{*}{ Spearman's rho } & \multirow{3}{*}{$\begin{array}{l}\text { Keterampilan } \\
\text { Sosial }\end{array}$} & Correlation Coefficient & 1.000 & $.992^{* *}$ \\
\hline & & Sig. (2-tailed) & . & .000 \\
\hline & & $\mathrm{N}$ & 26 & 26 \\
\hline & \multirow{3}{*}{$\begin{array}{l}\text { Prestasi } \\
\text { Belajar }\end{array}$} & Correlation Coefficient & $.992^{* *}$ & 1.000 \\
\hline & & Sig. (2-tailed) & .000 & \\
\hline & & $\mathrm{N}$ & 26 & 26 \\
\hline
\end{tabular}

Seperti yang telah di bahas sebelumnya, pengujian korelasi adalah pengujian yang bertujuan untuk menguji hubungan antara dua variabel, oleh sebab itu berikut akan di bahas hasil analisis korelasi untuk melihat hubungan antara dua variabel yaitu keterampilan sosial dan prestasi belajar. Dari hasil analisis di atas, dapat dilihat bahwa jumlah sampel 26 orang responden, Koefisien korelasi keterampilan sosial dengan prestasi belajar atau $r$ hitung sebesar 0,992, dan nilai sig. (2-tailet) sebesar 0,000, Berdasarkan table output maupun $r$ table di atas, di ketahui jumlah sampel atau $\mathrm{N}$ adalah 26 dengan nilai koefisien korelasi (spearman correlation) antara variabel keterampilan social dengan prestasi belajar sebesar 0,992 atau $r$ hitung sebesar 0,992, Nilai sig. (2-tailet) sebesar 0,000 . Dan nilai $r$ table sebesar 0,388 , itu artinya $0,992>0,388$. Dan $0,000<0,005$, maka dengan demikian dapat dikatakan terdapat hubungan positif yang signifikan antara keterampilan social dengan prestasi belajar siswa. 


\section{SIMPULAN DAN SARAN}

\section{A. Simpulan}

Berdasarkan penelitian yang telah dilakukan, dapat disimpulkan beberapa hal diantaranya: 1) diketahui tingkat kekuatan (Keeratan) hubungan variabel keterampilan sosial dengan prestasi belajar melalui analisis koefisien korelasi atau $r$ hitung sebesar $0,992^{* *}$, berdasarkan pedoman di atas, dari 0,800-1,000 dinyatakan sangat kuat. Artinya, tingkat kekuatan hubungan (Korelasi) antara variabel keterampilan sosial dengan prestasi belajar sangat kuat. Tanda bintang $\left({ }^{* *}\right)$ artinya korelasi bernilai signifikan pada angka signifikansi sebesar 0,05, 2) Diketahui arah (jenis) hubungan variabel keterampilan sosial dengan prestasi belajar melalui Angka koefisien korelasi pada hasil $r$ hitung di atas, bernilai positif, yaitu 0,992, sehingga hubungan kedua variabel tersebut bersifat searah (jenis hubungan searah), dengan demikian dapat diartikan bahwa jika keterampilan sosial semakin di tingkatkan maka prestasi belajarpun semakin meningkat, 3) Diketahui tingkat signifikansi hubungan kedua variabe, Berdasarkan output $r$ hitung diatas, diketahui nilai signifikan atau sig. (2-tailed) sebesar 0,000, karena nilai sig. (2-tailed) 0,000< lebih kecil dari 0,05 maka artinya ada hubungan yang signifikan (berarti) antara variabel keterampilan sosial dengan prestasi belajar, maka kesimpulan dalam penelitian ini adalah terdapat hubungan signifikan yang sangat kuat dan searah antara variable keterampilan social dengan prestasi belajar.

\section{B. SARAN}

Berdasarkan kesimpulan dapat diberikan saran-saran diantaranya: 1) Bagi guru dan siswa sebaiknya berupaya meningkatkan hubungan dan interaksi sosial baik antara guru dengan siswa maupun antara siswa dengan siswa, sehingga dalam hal ini akan membantu siswa meningkatkan prestasi belajarnya, 2) Bagi siswa di harapkan dapat mempertahankan dan meningkatkan keterampilan sosialnya, baik dengan melatih diri dan menerima dukungan dari luar dan dari dalam dirinya. Serta mampu berinterkasi secara baik dengan teman di lingkungan sekolah.

\section{DAFTAR RUJUKAN}

Ahmadi, A. (2009). Psikologi Sosial. Jakarta: PT Rineka Cipta.

Arikunto, S. (2010). Dasar-dasar Evaluasi pendidikan.(edisi revisi).Jakarta : PT Bumi Aksara

Arikunto, S. (2007).Dasar-Dasar Evaluasi Pendidikan.Jakarta : PTBumi Aksara.

Fahmi, I. (2014). Pengaruh Model Pembelajaran Kooperatif Tipe Team Accelerated Instruction (TAI) Terhadap Keterampilan Sosial Matematik Siswa Kelas 8 di SMP Negeri 3 Tangerang. Uin Syarif Hidayatullah. (Jurnal penelitian 2014). Di ambil dari, ejournal.gunadarma.ac.id/index.php/pesat /article/download/305/210/ diakses pada hari rabu, 10 juli 2019)

Sugiyono, (2017). Metode Penelitian Kuantitatif, Kualitatif, dan R\&D. Bandung: Alfabeta.

Yulia, S. (2010). Penerapan Metode Bermain Peran (role playing) dalam Meningkatkan KeterampilanSosial dan Kemampuan Berbicara Anak Usia Dini. ISSN 1412-565X (Jurnal.upi.edu/file/4-yulia_siska-edit.pdf/Di buka pada hari rabu, 10 juli 2019)

Yusuf, M, \& Legowo E, (2007).Mengatasi Kebiasaan Buruk Anak dalam Belajar melalui Pendekatan Modifikasi Perilaku.Jakarta: Prestasi Pustaka.

Winarsunu, T. (2017). Statistika dalam penelitian psikologi dan pendidikan. Malang: Universitas Muhammadiah Malang.

Enung Nurhasanah. (2021). Pengembangan Multimedia Pembelajaran Sejarah Perkembangan Islam Berbasis Macromedia Flash untuk Meningkatkan Hasil Belajar Mahasiswa. Ainara Journal Uurnal Penelitian Dan PKM Bidang Ilmu Pendidikan),2(3), 148-153. Retrieved from http://journal.ainarapress.org/index.php/ainj/article/view/69 